\title{
ISOTOPIC POWER MATERIALS \\ DEVELOPMENT PROGRESS REPORT \\ FOR MAY 1972
}

R. G. Donnelly THIS DOCUMENT CONFIRMED AS
UNCLASSIFIED
DIVSION GF CLASSIFICATION

BY QHE CHKaSSIFICATION DATE Ftrabaram

\section{OAK RIDGE NATIONAL LABORATORY}

OPERATEO BY UNION CARBIOE CORPORATION - FOR THE U.S. AIOMIC ENERGY COMMISSION 


\section{DISCLAIMER}

This report was prepared as an account of work sponsored by an agency of the United States Government. Neither the United States Government nor any agency Thereof, nor any of their employees, makes any warranty, express or implied, or assumes any legal liability or responsibility for the accuracy, completeness, or usefulness of any information, apparatus, product, or process disclosed, or represents that its use would not infringe privately owned rights. Reference herein to any specific commercial product, process, or service by trade name, trademark, manufacturer, or otherwise does not necessarily constitute or imply its endorsement, recommendation, or favoring by the United States Government or any agency thereof. The views and opinions of authors expressed herein do not necessarily state or reflect those of the United States Government or any agency thereof. 


\section{DISCLAIMER}

Portions of this document may be illegible in electronic image products. Images are produced from the best available original document. 
This report was prepared as an account of work sponsored by the United States Government Neither the United States nor the United States Atomic Energy Commission, nor any of their employees, nor any of their contractors, subcontractors, or their employees, makes any warranty, express or implied, or assumes any legal liability or responsibility for the accuracy, completeness or usefulness of anv information, apparatus, product or process disclosed, or represents that its use would not infringe privately owned rights 
ORNL-TM-3865

Contract No. W-7405-eng-26

\title{
ISOTOPIC POWER MATERIALS DEVELOPMENT PROGRESS REPORT FOR MAY 1972
}

\author{
R. G. Donne1ly
}

Metals and Ceramics Division

\section{NOTICE}

This report was prepared as an account of work sponsored by the United States Government. Neither the United States nor the United States Atomic Energy Commission, nor any of their employees, nor any of their contractors, subcontractors, or their employees, makes any warranty, express or implied, or assumes any legal liability or responsibility for the accuracy, completeness or usefulness of any information, apparatus, product or process disclosed, or represents that its use would not infringe privately owned rights.

\section{JUNE 1972}

NOTICE This document contains information of a preliminary noture and was prepared primarily for internal use of the Oak Ridge National Laboratory it is subject to revision or correction ond therefore does not represent a final report

\footnotetext{
OAK RIDGE NATIONAL LABORATORY

Oak Ridge, Tennessee 37830

UNION CARBIDE CORPORATION

for the

U.S. ATOMIC ENERGY COMMISSION
} 
page blank

ii 
CONTENTS

$\underline{\text { Page }}$

CLADDING MATERIALS PROGRAM . . . . . . . . . . . . . . . 1

Characterization of $\mathrm{Pt}-\mathrm{Rh}-\mathrm{W}$ Alloys . . . . . . . . . . 1

Characterization of Iridium . . . . . . . . . . . . . 4

Iridium Purification and Scrap Recycle . . . . . . . . . 5

REFRACTORY ALLOYS PROGRAM. . . . . . . . . . . . . . 6

Effect of Oxygen Contamination on the Mechanical

Properties of Molybdenum-Base Alloys . . . . . . . . . . 6

Effect of Carbon Monoxide Contamination on the

Mechanical Properties of Molybdenum-Base Alloys . . . . . 7

MATERIALS COMPATIBILITY TESTING FOR THE LASL-DART PROJECT . . . 8 


\author{
Characterization of Pt-Rh-W Alloys \\ J. H. Erwin and $H$. Inouye
}

\begin{abstract}
We continued the evaluation of rolled $\mathrm{Pt}-\mathrm{Rh}-\mathrm{W}$ alloy sheet. Previously we reported ${ }^{l}$ results of tensile and modified Olsen cup tests of two $P t-26 \%$ $\mathrm{Rh}-8 \% \mathrm{~W}$ sheets, $\mathrm{Pt}-1 \mathrm{D}$ with known tungsten segregation, and Pt-1ER without obvious tungsten segregation, following heat treatment in the range 900 to $1300^{\circ} \mathrm{C}$. Bend test results of similarly heat-treated samples from the two sheets are summarized in Table 1. In this respect, these data verify the 1000 to $1100^{\circ} \mathrm{C}$ temperature range indicated by the tensile and cup tests as optimum heat treatment for the $21 \%$ cold-rolled alloy. The calculated elongation and bend strength are 25 to $50 \%$ higher than the values obtained from tensile tests. This is perhaps due to differences in sample geometry and calculation methods. Duplicate samples for a given heat treatment showed occasional wide differences in the bend angle to failure. Examination of the fractures reveal grain boundary separation in the less ductile samples. We associated the grain boundary fracture with tungsten segregation from previous experience with the Pt-1D sheet; however, examination of samples by metallography has not revealed any differences in grain boundaries of the samples.
\end{abstract}

The tensile properties of $\mathrm{Pt}-26 \% \mathrm{Rh}-8 \% \mathrm{~W}$ (heat 1ER) specimens taken from an $0.030 \times 12 \times 12-$ in. sheet are shown in Table 2 . These data show consistent and nondirectional properties for a given heat treatment. The ductility increases uniformly with temperature from approximately $11 \%$ at room temperature to approximately $50 \%$ at $1316^{\circ} \mathrm{C}$. On the other hand, the reduction in area is seen to increase abruptly from approximately $6 \%$ at room temperature to $100 \%$ at and above $760^{\circ} \mathrm{C}$. Table 3 shows that the calculated impact capabilities at $1316^{\circ} \mathrm{C}$ of the alloy [defined as 0.5 (UTS + YS) $\times$ fracture strain] increases somewhat with the strain rate by virtue of corresponding increases in the ultimate tensile and yield strength. The impact values for $\mathrm{T}-111$ and iridium are 11,000 and 7,400 in.-1b/in. ${ }^{3}$, respectively. The superior impact values of the platinum alloy arise from the fact that the yield strength is about $86 \%$ of the ultimate strength and that the fracture ductilities are also higher than T-111 or iridium.

To determine the effect of the rhodium content in $\mathrm{Pt}-\mathrm{Rh}-\mathrm{W}$ alloys, we increased the rhodium content from the previous $26 \%$ to $30 \%$ at the $8 \% \mathrm{~W}$ level。 One small ingot (heat $\mathrm{Pt}-4 \mathrm{~A}$ ) was fabricated into sheet in a manner similar to previous procedure with excellent results, An 01sen cup test on a blank heat treated for $1 \mathrm{hr}$ at $990^{\circ} \mathrm{C}$ in vacuum produced a full 7/8in.-diam hemisphere with only two small surface cracks. This is in contrast with failure of the $\mathrm{Pt}-26 \% \mathrm{Rh}-8 \% \mathrm{~W}$ alloy (Pt-1ER) blank at a cup

\footnotetext{
${ }^{\mathrm{l}} \mathrm{R}$ 。 G。 Donnelly, Isotopic Power Materials Development Progress Report for April 1972, ORNL-TM-3828, Oak Ridge National Laboratory.
} 
Table 1. Bend Test Results of 0.030-in.-thick Platinum-Rhodium-Tungsten Alloy Sheet (Standard $2 \mathrm{~T}$ bend test at a rate of $0.2 \mathrm{in.} / \mathrm{min}$ )

\begin{tabular}{|c|c|c|c|c|c|c|c|c|c|}
\hline \multirow{2}{*}{$\begin{array}{c}\text { Heat Treatment }\left({ }^{\circ} \mathrm{C}\right) \\
(1 \mathrm{hr} \text { vac })\end{array}$} & \multirow{2}{*}{$\frac{\text { Maximum }}{\mathrm{Pt}-1 \mathrm{D}^{\mathrm{a}}}$} & \multirow{2}{*}{\multicolumn{2}{|c|}{$\frac{\text { Bend Angle (deg) }}{\text { Pt-1ER }}$}} & \multicolumn{3}{|c|}{ Elongation $(\%)$} & \multicolumn{2}{|c|}{ Bend Strength } & \multirow{2}{*}{$\frac{(\mathrm{ks} 1)}{\mathrm{Pt}-4 \mathrm{~A}^{\mathrm{C}}}$} \\
\hline & & & & $\overrightarrow{\mathrm{Pt}-1 \mathrm{D}^{\mathrm{a}}}$ & Pt-1ER ${ }^{b}$ & $\mathrm{Pt}-4 \mathrm{~A}^{\mathrm{C}}$ & $\overline{\mathrm{Pt}-1 \mathrm{D}^{\mathrm{a}}}$ & $P t-1 E R^{b}$ & \\
\hline \multicolumn{10}{|c|}{ Transverse Samples Bent Parallel t } \\
\hline 900 & 61 & 53 & 55 & 12.3 & 11.6 & 11.7 & 309 & 332 & 329 \\
\hline 950 & 86 & 55 & $\mathbf{x}$ & 17.2 & 12.0 & $\mathbf{x}$ & 286 & 304 & $\mathbf{x}$ \\
\hline 990 & $\mathbf{x}$ & 99 & 108 & $\mathrm{x}$ & 19.0 & $>20$ & 196 & 209 & 214 \\
\hline 1000 & 65 & $\mathbf{x}$ & $\mathbf{x}$ & 13.4 & $\mathbf{x}$ & $\mathbf{x}$ & 258 & $\mathbf{x}$ & $\mathbf{x}$ \\
\hline 1100 & 81 & 50 & 108 & 16.5 & 10.7 & $>20$ & 153 & 145 & 152 \\
\hline 1200 & 37 & $\mathbf{x}$ & $\mathbf{x}$ & 8.2 & $\mathbf{x}$ & $\mathbf{x}$ & 131 & $\mathbf{x}$ & $\mathbf{x}$ \\
\hline 1300 & 35 & 42 & 87 & 8.1 & 9.5 & 18.0 & 118 & 115 & 136 \\
\hline \multicolumn{10}{|c|}{ Longitudinal Samples Bent Transverse to } \\
\hline 900 & 70 & 46 & $\mathbf{x}$ & 13.9 & 10.0 & $\mathbf{x}$ & 292 & 313 & $\mathbf{x}$ \\
\hline 950 & 86 & 64 & $\mathbf{x}$ & 19.1 & 13.3 & $\mathbf{x}$ & 269 & 300 & $\mathbf{x}$ \\
\hline 1050 & 70 & 52 & $\mathbf{x}$ & 14.6 & 11.2 & $\mathbf{x}$ & 153 & 167 & $\mathbf{x}$ \\
\hline 1100 & 89 & 50 & $x$ & 17.4 & 10.6 & $\mathbf{x}$ & 141 & 143 & $\mathbf{x}$ \\
\hline 1200 & 45 & 45 & $\mathbf{x}$ & 9.7 & 9.7 & $x$ & 125 & 129 & $\mathbf{x}$ \\
\hline 1300 & 40 & 46 & $x$ & 8.7 & 9.8 & $\mathbf{x}$ & 112 & 118 & $\mathbf{x}$ \\
\hline
\end{tabular}

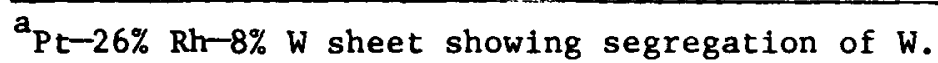

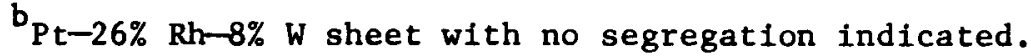

${ }^{\mathrm{C}} \mathrm{Pt}-30 \% \mathrm{Rh}-8 \% \mathrm{~W}$ sheet.

$\mathbf{x}=$ no sample. 
height of only 0.467 in. Results of the bend tests on this alloy are also given in Table 1. Samples heat treated at both 990 and $1100^{\circ} \mathrm{C}$ withstood a $90^{\circ} 2 \mathrm{~T}$ bend test.

Table 2. Tensile Properties of $0.030 \times 12 \times 12-1$. Sheet of $\mathrm{Pt}-26 \% \mathrm{Rh}-8 \% \mathrm{~W}$ (heat Pt-1ER)

\begin{tabular}{|c|c|c|c|c|c|}
\hline $\begin{array}{l}\text { 1-Hr Heat } \\
\text { Treatment } \\
\quad\left({ }^{\circ} \mathrm{C}\right)\end{array}$ & $\begin{array}{l}\text { Test } \\
\text { Temperature } \\
\left({ }^{\circ} \mathrm{C}\right)\end{array}$ & $\begin{array}{l}\text { Ultimate } \\
\text { Tensile } \\
\text { Strength (psi) }\end{array}$ & $\begin{array}{l}\text { Yield }^{b} \\
\text { Strength } \\
\quad \text { (psi) }\end{array}$ & $\begin{array}{c}\text { Elongation } \\
(\%)\end{array}$ & $\begin{array}{c}\text { Reduction } \\
\text { in Area } \\
(\%)\end{array}$ \\
\hline \multicolumn{6}{|c|}{ Longitudinal to Rolling Direction } \\
\hline $\begin{array}{l}1000 \\
1100 \\
1200 \\
1300 \\
1200 \\
1200 \\
1200\end{array}$ & $\begin{array}{r}\text { Room } \\
\text { Room } \\
\text { Room } \\
\text { Room } \\
760 \\
1093 \\
1316\end{array}$ & $\begin{array}{r}152,000 \\
104,800 \\
92,100 \\
80,700 \\
74,400 \\
38,400 \\
17,000\end{array}$ & $\begin{array}{r}103,200 \\
53,100 \\
47,300 \\
40,400 \\
28,700 \\
18,900 \\
14,900\end{array}$ & $\begin{array}{l}11.3 \\
13.5 \\
11.5 \\
11.1 \\
27.8 \\
30.8 \\
52.0\end{array}$ & $\begin{array}{r}11.9 \\
6.1 \\
7.5 \\
5.7 \\
\sim 100 \\
\sim 100 \\
\sim 100\end{array}$ \\
\hline \multicolumn{6}{|c|}{ Transverse to Rolling Direction } \\
\hline $\begin{array}{l}1000 \\
1100 \\
1200 \\
1300\end{array}$ & $\begin{array}{l}\text { Room } \\
\text { Room } \\
\text { Room } \\
\text { Room }\end{array}$ & $\begin{array}{r}150,300 \\
101,000 \\
91,600 \\
74,800\end{array}$ & $\begin{array}{r}109,700 \\
55,000 \\
49,400 \\
42,000\end{array}$ & $\begin{array}{r}13.8 \\
13.3 \\
11.3 \\
9.3\end{array}$ & $\begin{array}{r}15.3 \\
5.3 \\
7.2 \\
6.0\end{array}$ \\
\hline
\end{tabular}

Table 3. The Effect of Strain Rate on the Tensile Properties of Pt $-26 \% \mathrm{Rh}-8 \%$ W Sheet at $1316^{\circ} \mathrm{C}^{\mathrm{a}}$

\begin{tabular}{ccccc}
\hline $\begin{array}{c}\text { Strain Rate } \\
\text { (in./in./min) }\end{array}$ & $\begin{array}{c}\text { U1timste Tensile } \\
\text { Strength (psi) }\end{array}$ & $\begin{array}{c}\text { Yield } \\
\text { Strength } \\
\text { (psi) }\end{array}$ & $\begin{array}{c}\text { Elongation } \\
(\%)\end{array}$ & $\begin{array}{c}\text { Impact Values }^{\mathrm{c}} \\
\text { (in.-1b/in. }{ }^{3} \text { ) }\end{array}$ \\
\hline 0.05 & 17,000 & 14,900 & 52.0 & 16,600 \\
0.10 & 20,100 & 17,600 & 56.5 & 21,200 \\
0.20 & 20,700 & 16,900 & 47.0 & 17,700 \\
\hline
\end{tabular}

${ }^{a} 0.030$-in.-thick sheet of heat Pt-1ER annealed $1 \mathrm{hr}$ at $1200^{\circ} \mathrm{C}$.

$\mathrm{b}_{0.2 \%}$ offset yield strength.

c 0.5 (UTS + YS) $\times$ fracture strain.

The tensile properties of heat $\mathrm{Pt}-4 \mathrm{~A}$ are shown in Table 4. At room temperature this alloy is stronger and more ductile than $\mathrm{Pt}-26 \% \mathrm{Rh}-8 \% \mathrm{~W}$; however, at 1093 and $1316^{\circ} \mathrm{C}$ a significant amount of scatter was observed. Because the specimens showing poor tensile properties were taken from the same side of the rolled sheet, it is suspected that contamination or segregation has occurred. 
Table 4. Tensile Properties of 0.030-in.-thick $\mathrm{Pt}-26 \% \mathrm{Rh}-8 \%$ W $(\text { Heat } \mathrm{Pt}-4 \mathrm{~A})^{\mathrm{a}}$

\begin{tabular}{|c|c|c|c|c|}
\hline $\begin{array}{l}\text { Test } \\
\text { Temperature } \\
\left({ }^{\circ} \mathrm{C}\right)\end{array}$ & $\begin{array}{l}\text { Ultimate Tensile } \\
\text { Strength } \\
\text { (psi) }\end{array}$ & $\begin{array}{l}0.2 \% \text { offset } \\
\text { Yield Strength } \\
\text { (psi) }\end{array}$ & $\begin{array}{c}\text { Elongation } \\
(\%)\end{array}$ & $\begin{array}{l}\text { Reduction } \\
\text { in Area } \\
(\%)\end{array}$ \\
\hline \multicolumn{5}{|c|}{ Longitudinal to Rolling Direction } \\
\hline $\begin{array}{l}\text { Room } \\
1093^{b} \\
1316\end{array}$ & $\begin{array}{r}115,000 \\
38,000 \\
19,800\end{array}$ & $\begin{array}{l}53,200 \\
20,500 \\
16,500\end{array}$ & $\begin{array}{l}17.8 \\
16.8 \\
46.8\end{array}$ & $\begin{array}{l}9.1 \\
13.4 \\
57\end{array}$ \\
\hline \multicolumn{5}{|c|}{ Transverse to Rolling Direction } \\
\hline $\begin{array}{l}\text { Room } \\
760_{\mathrm{b}} \\
1093_{\mathrm{b}} \\
1316^{6}\end{array}$ & $\begin{array}{r}108,200 \\
75,100 \\
35,700 \\
15,500\end{array}$ & $\begin{array}{l}50,800 \\
30,200 \\
19,500 \\
15,000\end{array}$ & $\begin{array}{l}18.8 \\
30.2 \\
18.3 \\
28.0\end{array}$ & $\begin{array}{r}9.1 \\
35.1 \\
35.4 \\
11.9\end{array}$ \\
\hline \multicolumn{5}{|c|}{$\begin{array}{l}{ }^{\mathrm{a}} \text { Specimens annealed } 1 \mathrm{hr} \text { at } 1200^{\circ} \mathrm{C} \text {, tested at } 0.05 \mathrm{in.} / \mathrm{in.} / \mathrm{min} \text {. } \\
\mathrm{b}_{\text {Specimens showed numerous cracks in gage length after testing. }}\end{array}$} \\
\hline \multicolumn{5}{|c|}{ Characterization of Iridium } \\
\hline
\end{tabular}

To show the effect of a heat pulse during re-entry of the MHW heat source on the tensile properties of iridium, sheet specimens were heated $5 \mathrm{~min}$ at $2000^{\circ} \mathrm{C}$ in vacuum after recrystallization for $1 \mathrm{hr}$ at $1500^{\circ} \mathrm{C}$. The tensile results for such a treatment are shown in Table 5 together with those reported previously. ${ }^{2}$ The mechanical properties of the specimens recrystallized $1 \mathrm{hr}$ at $1500^{\circ} \mathrm{C}$ alone (Case A in Table 5) behave normally in terms of temperature dependence of strength and ductility. The specimens subjected to the heat pulse (Case B in Table 5) behave abnormally as follows:

1. The yield strength is extremely low at low temperatures.

2. Both the ultimate and yield strengths show minimum values at $1093^{\circ} \mathrm{C}$.

3. The ductility is low up to $1093^{\circ} \mathrm{C}$, and it also has a minimum value $(6.4 \%)$ at $1093^{\circ} \mathrm{C}$.

4. The heat pulse has no effect on the ductility at the impact temperature, that is, $1316^{\circ} \mathrm{C}$.

To characterize the fabricability of iridium, 1/8-in. iridium plate received from Engelhard Industries was warm-rolled at $825^{\circ} \mathrm{C}$ in air. This temperature was chosen because the oxidation rate of iridium is

${ }^{2}$ R. G. Donnelly, Isotopic Power Materials Development Progress Report for December 1971, ORNL-CF-72-1-13, Oak Ridge National Laboratory. 
low below $900^{\circ} \mathrm{C}$. The result indicates that the fabricability of iridium is good at $825^{\circ} \mathrm{C}$. The rolled plate shows no surface or edge cracks when reduced to 55 mils with one intermediate anneal to $1280^{\circ} \mathrm{C}$. A part of the stock was further rolled to $30 \mathrm{mils}$ at room temperature. However, some surface cracks developed near the edge of the specimen.

Table 5. Tensile Properties of Iridium Specimens Under Two Heat Treatments: A - Recrystallized $1 \mathrm{hr}$ at $1500^{\circ} \mathrm{C}$

B - 5-min anneal at $2000^{\circ} \mathrm{C}$ after recrystallizing $1 \mathrm{hr}$ at $1500^{\circ} \mathrm{C}$

\begin{tabular}{|c|c|c|c|c|c|c|}
\hline \multirow{2}{*}{$\begin{array}{l}\text { Testing } \\
\text { Temp }\left({ }^{\circ} \mathrm{C}\right)\end{array}$} & \multicolumn{2}{|c|}{ Tensile Strength (psi) } & \multicolumn{2}{|c|}{ Yield Strength (psi) } & \multicolumn{2}{|c|}{ Elongation (\%) } \\
\hline & $A$ & $\mathrm{~B}$ & $\bar{A}$ & B & $\overline{\mathrm{A}}$ & B \\
\hline Room & 56,000 & 46,100 & 25,000 & 11,500 & 5.7 & 8.5 \\
\hline 1093 & 35,000 & 13,500 & 16,000 & $9,000^{b}$ & 39.6 & 6.4 \\
\hline 1316 & 26,000 & 23,000 & 13,000 & 10,500 & 38 & 33.7 \\
\hline
\end{tabular}

${ }^{a} 0.020-i n .-t h i c k$ sheet, strain rate $0.05 \mathrm{in.} / \mathrm{in.} / \mathrm{min}$.

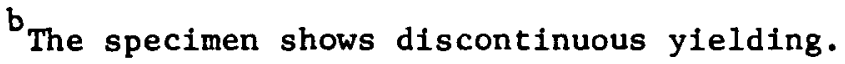

Iridium Purification and Scrap Recycle

H. Inouye

A laboratory development effort directed toward the purification of iridium and leading to a process for producing high-purity iridium sheet has been initiated. Tentatively, two distinct routes are contemplated. First, commercial iridium powder as purchased from vendors will be treated in acids and hydrogen to remove impurities prior to melting. The second route constitutes the purification and/or recycling of scrap.

Some difficulty is being encountered in obtaining iridium from vendors. No iridium powder is on hand now for conducting the first part of the study. Consequently, the second route has become significantly more important to the overall program plan and is therefore being elevated to an active status.

Currently, a literature survey is being conducted on the dissolution and purification of iridium, and the available information should be evaluated this month. In the meantime, some preliminary experiments for the purification of iridium scrap by a pyrometallurgical process, which is described below, has been initiated.

Iridium is insoluble in most acids, and any dissolution method would also dissolve the impurities. Separation of iridium in this case would be from the soluble salts by a chemical process. The pyrometallurgical process takes advantage of the relatively high oxidation rate of iridium to gaseous 
iridium oxide ${ }^{3,4}$ in flowing oxygen and its separation from impurities as solid $\mathrm{IrO}_{2}$. The condensed $\mathrm{IrO}_{2}$ is then reduced to powder in $\mathrm{H}_{2}$. To demonstrate feasibility, Ir -3 wt $\%$ Nb scrap was pulverized to a powder (as it is very brittle) to increase the surface area, then oxidized in flowing oxygen at $1100^{\circ} \mathrm{C}$. Black crystals of $\mathrm{IrO}_{2}$ deposited in the cooler portion of the quartz tube, and a solid white powder of $\mathrm{Nb}_{2} \mathrm{O}_{5}$ was left as a residue in the hot zone of the furnace tube. Based on the vapor pressures of the oxides at $1100^{\circ} \mathrm{C}$, impurities, such as $\mathrm{Si}, \mathrm{Cr}, \mathrm{Nb}, \mathrm{Th}, \mathrm{Fe}, \mathrm{Al}, \mathrm{Ni}, \mathrm{Zr}$, Hf, etc., will be removed from impure iridium as solid oxide residues in the distillation retort. The condensate of $\mathrm{IrO}_{2}$ which may contain oxides of Mo, $\mathrm{W}$, or Re can be removed by acids or $\mathrm{NH}_{4} \mathrm{OH}$ since $\mathrm{IrO}_{2}$ is insoluble in these solvents. Carbon and sulfur impurities are oxidized to noncondensable gases under these conditions and are removed in this form.

\section{REFRACTORY ALLOYS PROGRAM}

\section{Effect of Oxygen Contamination on the Mechanical \\ Properties of Molybdenum-Base Alloys}

$$
\text { C. T. Liu }
$$

Table 6 shows the effect of oxygen doping on the mechanical properties of TZM at the Pioneer impact temperature, that is, $1316^{\circ} \mathrm{C}$. The ductility decreases seriously with doping time and is almost lost after $207 \mathrm{hr}$ of exposure at $1000^{\circ} \mathrm{C}$. Because tensile tests at lower temperatures showed the same behavior, one concludes that the ductility of oxygen-contaminated TZM does not improve with an increase in temperature.

Table 6. Tensile Properties at $1316^{\circ} \mathrm{C}$ of 20 -mil-thick TZM Sheet Specimens Contaminated with Oxygen $^{a}$

\begin{tabular}{ccc}
$\begin{array}{c}\text { Doping Time } \\
(\mathrm{h} r)\end{array}$ & $\begin{array}{c}\text { Elongation } \\
(\%)\end{array}$ & $\begin{array}{c}\text { Tensile Strength } \\
\text { (psi) }\end{array}$ \\
\hline 0 & 30 & 22,000 \\
25 & 8.0 & 28,700 \\
50 & 6.5 & 27,800 \\
207 & 0.5 & 31,300 \\
\hline
\end{tabular}

${ }^{\mathrm{a}}$ Doped in $1 \times 10^{-5}$ torr oxygen at $1000^{\circ} \mathrm{C}$.

${ }^{3}$ J. R. Ogren et al., Radioisotope Propulsion Technology Program, Vol. III, STL-517-0049 (Oct. 1966).

${ }^{4}$ C. B. Alcock and G. W. Hooper, Proc. Royal Soc. A254, 551-61 (1960). 
Effect of Carbon Monoxide Contamination on the Mechanical Properties of Molybdenum-Base Alloys

$$
\text { C. T. Iiu }
$$

TZM specimens were exposed to $1 \times 10^{-5}$ torr $\mathrm{CO}$ at $1000^{\circ} \mathrm{C}$ for different periods of time to determine in simulation its compatibility with gases outgassed from graphite and Min-K 1301. The results of tensile tests are presented in Table 7 . The tensile strength shows a general increase with doping time. The ductility at room temperature drops sharply between $240-$ and $500-\mathrm{hr}$ exposures at $1000^{\circ} \mathrm{C}$ but remains constant at a value of approximately $30 \%$ at $1316^{\circ} \mathrm{C}$. As shown in Table 7 , the ductility after $1000 \mathrm{hr}$ of exposure is a maximum at $825^{\circ} \mathrm{C}$. TZM doped with $\mathrm{CO}$ behaves quite differently from that doped in oxygen. Complete characterization requires more data.

Table 7. Tensile Properties of 20-mil-thick TZM Sheet Specimens Contaminated with Cobalt at $1 \times 10^{-5}$ Torr and $1000^{\circ} \mathrm{C}$ and Tested at Various Temperatures

\begin{tabular}{ccc}
\hline $\begin{array}{c}\text { Doping Time } \\
(\mathrm{hr})\end{array}$ & $\begin{array}{c}\text { Elongation } \\
(\%)\end{array}$ & $\begin{array}{c}\text { Tensile Strength } \\
\text { (psi) }\end{array}$ \\
\hline
\end{tabular}

Room Temperature

$\begin{array}{rcc}0 & 37 & 79,000 \\ 240 & 37.3 & 80,500 \\ 500 & 3.9 & 80,000 \\ 1000 & 1.1 & 83,800 \\ & \frac{825^{\circ} \mathrm{C}}{2} & \\ 0 & 24.8 & 45,000 \\ 1000 & 15.3 & 50,700 \\ & & \\ & \frac{1093^{\circ} \mathrm{C}}{\mathrm{a}} & 33,000^{\mathrm{a}} \\ 0 & 3.2 & 40,800 \\ 1000 & & \\ & 30^{\frac{1316^{\circ} \mathrm{C}}{\mathrm{a}}} & 22,000 \\ 0 & 29 & 28,000 \\ 240 & 29.7 & 27,000 \\ 500 & & \end{array}$

${ }^{a}$ Data collected from General Electric, Multi-Hundred Watt, Radioisotope Thermoelectric Generator Program, GESP-7034 (March 1970). 


\section{I'ATERIALS CONPATIBILITY TESTING FOR THE LASL-DART PROJECT \\ J. R. Distefano}

Compatibility couples involving several non-fuel materials being considered in constructing the DART were examined after $500 \mathrm{hr}$ at 1300,1400 , and $1500^{\circ} \mathrm{C}$, and the data are summarized in Tables 8-10. Only the couples tested at $1400^{\circ} \mathrm{C}$ were examined in detail.

From the data it would appear that graphite is very compatible with BeO, W, $\mathrm{Re}$, and $\mathrm{Pt}-\mathrm{Rh}-\mathrm{W}$ up to $1500^{\circ} \mathrm{C}$. In cases where $\mathrm{W}$ and Re cracked, it did not appear to be the result of interaction with the graphite and probably occurred during cutting and/or mounting.

All three oxides, $\mathrm{ZrO}_{2}, \mathrm{HfO}_{2}$, and $\mathrm{BeO}$, showed good compatibility with the metals they were tested against. Visual observation indicated some discoloration of both $\mathrm{ZrO}_{2}$ and $\mathrm{HfO}_{2}$, and relatively large weight losses were noted in both those oxides. Beryllium oxide showed little tendency to interact even in the $1500^{\circ} \mathrm{C}$ tests that were examined. However, a rather serious mass transfer effect was found in the closed tungsten capsule that contained $\mathrm{BeO}$. The tungsten showed rather large weight losses and had an etched appearance indicative of dissolution. Since this was not observed in the couple that was tested in dynamic vacuum, it seems likely that oxygen was involved in the process. One possible type of reaction is

$$
\mathrm{W}+\mathrm{x} / 2=\mathrm{WO}_{\mathrm{x}}(\mathrm{g}) \text {. }
$$

The source of oxygen is the BeO, and for vapor transport to occur, the reverse reaction must take place somewhere in the system. The driving force for the reverse reaction is difficult to postulate. An activity gradient could occur from a temperature gradient, pressure change, or energy change as a result of geometrical considerations. For a closed system of the type we have, it is hard to identify the reason for such an energy gradient to occur. However, we previously found the same type of thing when we exposed tungsten to $\mathrm{Cm}_{2} \mathrm{O}_{3} \cdot{ }^{5}$

5J. R. DiStefano and K. H. Lin, Compatibizity of Curium Oxide with Refractory Metals at $1650^{\circ} \mathrm{C}$ and $1850^{\circ} \mathrm{C}$, ORNL-4773, Oak Ridge Nationa1 Laboratory (March 1972), pp. 21-36. 
Table 8. Summary of $1400^{\circ} \mathrm{C}$ Compatibility Test Data for LASL-DART Project

\begin{tabular}{|c|c|c|c|c|c|c|}
\hline $\begin{array}{l}\text { Sample } \\
\text { No. }\end{array}$ & Couple & $\begin{array}{l}\text { Visual } \\
\text { Observation }\end{array}$ & $\begin{array}{l}\text { Metallographic } \\
\text { Observations }\end{array}$ & $\begin{array}{l}\text { Chemical } \\
\text { Carbon } \\
\text { in Metal }\end{array}$ & $\frac{\text { is }(\text { wt } \%)}{\text { Oxygen }}$ & Hardness \\
\hline $1 \mathrm{~B}$ & $\mathrm{C}-\mathrm{Ta}$ & $R, S$ & $\begin{array}{l}\text { Two layers on Ta surface } \\
\text { to depth of } 3 \mathrm{mils}\end{array}$ & 0.024 & & $\begin{array}{l}\text { Matrix }=112 \mathrm{DPH} \\
\text { Layer }=1512 \mathrm{DPH}\end{array}$ \\
\hline $2 B$ & $\mathrm{C}-\mathrm{W}$ & NR & No interaction & 0.0017 & & Matrix $=375 \mathrm{DPH}$ \\
\hline 3B & C-Mo & $R, D, S$ & $\begin{array}{l}\text { Reaction zone in Mo to } \\
27 \text { mils deep }\end{array}$ & 0.050 & & $\begin{array}{l}\text { Matrix }=151 \mathrm{DPH} \\
\text { Layer }=1100 \mathrm{DPH}\end{array}$ \\
\hline 4B & $\mathrm{C}-\mathrm{BeO}$ & $\mathrm{D}$ & No interaction & 0.020 & & \\
\hline $5 B$ & $\mathrm{C}-\mathrm{Re}$ & $\mathrm{s}$ & $\begin{array}{l}\text { Re cracked. No surface } \\
\text { reaction zone, but Re either } \\
\text { heavily twinned or contains } \\
\text { needle-like precipitates } \\
\text { throughout }\end{array}$ & 0.012 & & Matrix $=381 \mathrm{DPH}$ \\
\hline 6B C & $C-(\mathrm{Mo}-50 \% \mathrm{Re})$ & $R, S, D$ & $\begin{array}{l}\text { Reaction zone in Mo- } 50 \text { wt \% } \\
\text { Re to } 56 \text { mils }\end{array}$ & & & $\begin{array}{l}\text { Matrix }=343 \mathrm{DPH} \\
\text { Layer }=1390 \mathrm{DPH}\end{array}$ \\
\hline $7 \mathrm{~B}$ & $C-(P t-R h-W)$ & $R, S, D$ & $\begin{array}{l}\text { Specimen joined to graphite, } \\
\text { but no reaction zone. Surface } \\
\text { of } \mathrm{Pt}-\mathrm{Rh}-\mathrm{W} \text { slightly roughened. }\end{array}$ & $0.02-1.03^{a}$ & & Matrix $=235 \mathrm{DPH}$ \\
\hline Mo-2 & $\mathrm{Mo}-\mathrm{ZrO}_{2}$ & $\mathrm{~F}, \mathrm{C}$ & No interaction & & 0.0059 & \\
\hline W-2 & $\mathrm{W}-\mathrm{ZrO}_{2}$ & $\mathrm{~F}, \mathrm{C}$ & No interaction & & 0.0008 & \\
\hline $\mathrm{Ta}-2$ & $\mathrm{Ta}-\mathrm{ZrO}_{2}$ & F,C & No interaction & & 0.0280 & \\
\hline Mo-5 & $\mathrm{Mo}-\mathrm{HfO}_{2}$ & $F, C, S R$ & No interaction & & 0.0130 & \\
\hline W-5 & $\mathrm{W}-\mathrm{HfO} \mathrm{O}_{2}$ & C & No interaction & & 0.0014 & \\
\hline $\mathrm{Ta}-5$ & $\mathrm{Ta}-\mathrm{HfO}_{2}$ & $\mathrm{~F}, \mathrm{C}$ & $\begin{array}{l}\text { Very slight }(<0.1 \mathrm{mll}) \\
\text { surface reaction }\end{array}$ & & 0.0300 & \\
\hline
\end{tabular}


Table 8. continued

\begin{tabular}{|c|c|c|c|c|c|}
\hline $\begin{array}{l}\text { Sample } \\
\text { No. }\end{array}$ & Couple & $\begin{array}{l}\text { Visual } \\
\text { Observation }\end{array}$ & $\begin{array}{l}\text { Metallographic } \\
\text { Observations }\end{array}$ & $\begin{array}{l}\text { is }(\text { wt } \%) \\
\text { Oxygen } \\
\text { in Metal }\end{array}$ & Hardness \\
\hline Mo-8 & $\mathrm{Mo-BeO}$ & NR & No interaction & 0.0074 & \\
\hline Mo-11 & $\mathrm{Mo}-\mathrm{BeO}$ & NR & No interaction & 0.0062 & \\
\hline W-8 & $\mathrm{W}-\mathrm{BeO}$ & NR & Slight surface roughness & 0.0012 & \\
\hline W-11 & $\mathrm{W}-\mathrm{BeO}$ & $\begin{array}{l}\mathrm{NR}, \mathrm{W} \\
\text { has etched } \\
\text { appearance }\end{array}$ & Slight surface roughness & 0.0006 & \\
\hline $\operatorname{Re}-1$ & $\mathrm{Re}-\mathrm{BeO}$ & NR & $\begin{array}{l}\text { Re surface irregular structure } \\
\text { either shows a Widmanstatten } \\
\text { second phase precipitate or is } \\
\text { very highly twinned }\end{array}$ & $<0.0001$ & \\
\hline $\begin{array}{r}(\text { Mo- } 50 \\
\text { Re })-1\end{array}$ & $\begin{array}{l}(\mathrm{Mo}-50 \mathrm{Re})- \\
\mathrm{BeO}\end{array}$ & NR & $\begin{array}{l}\text { Chain-like grain-boundary } \\
\text { precipitate throughout Mo-50Re }\end{array}$ & 0.0040 & \\
\hline Mo-14 & Mo-Re & $\mathrm{S}$ & $\begin{array}{l}\text { Three distinct layers in diffusion } \\
\text { zone. Some voids in Mo-rich layer. }\end{array}$ & & \\
\hline W-14 & W-Re & $\mathrm{S}$ & $\begin{array}{l}\text { Samples parted when cut. Re surface } \\
\text { rough; layer on W surface. Some voids } \\
\text { in W. }\end{array}$ & & \\
\hline$W-17$ & $\mathrm{~W}-(\mathrm{Mo}-50 \mathrm{Re})$ & NR & $\begin{array}{l}\text { Chain-like grain boundary phase } \\
\text { throughout Mo-50Re }\end{array}$ & & \\
\hline $\begin{array}{r}(\mathrm{Mo}-50 \\
\mathrm{Re})-3\end{array}$ & $\begin{array}{l}\text { (Mo-50Re)- } \\
\text { Ir }\end{array}$ & $\mathrm{D}$ & $\begin{array}{l}\text { Chain-like grain boundary phase } \\
\text { throughout Mo-50Re }\end{array}$ & & \\
\hline
\end{tabular}

${ }^{a}$ Some graphite stuck to surface of specimen. $R=$ visible reaction; $S=$ couple stuck together; $S R=s$ light reaction; $N R$ = no visible reaction; $D=$ surface of specimen discolored; $F$ = ceramic flaked, chipped, or cracked; $\mathrm{C}=$ ceramic discolored. 
Table 9. Summary of $1500^{\circ} \mathrm{C}$ Compatibility Test Data for LASL-DART Project

\begin{tabular}{|c|c|c|c|c|c|}
\hline \multirow{2}{*}{$\begin{array}{l}\text { Sample } \\
\text { No. }\end{array}$} & \multirow[b]{2}{*}{ Couple } & \multirow{2}{*}{$\begin{array}{l}\text { Visual } \\
\text { Observation }\end{array}$} & \multirow{2}{*}{$\begin{array}{l}\text { Metallographic } \\
\text { Observations }\end{array}$} & \multicolumn{2}{|c|}{ Chemical Analysis (wt \%) } \\
\hline & & & & $\begin{array}{l}\text { Carbon } \\
\text { in Metal }\end{array}$ & $\begin{array}{l}\text { Oxygen } \\
\text { in Meta1 }\end{array}$ \\
\hline $1 \mathrm{C}$ & $\mathrm{C}-\mathrm{Ta}$ & $S, R, D$ & & & \\
\hline $2 \mathrm{C}$ & $\mathrm{C}-\mathrm{W}$ & $S, \dot{R}$ & $\begin{array}{l}\text { W cracked - probably during } \\
\text { cutting. Slight surface } \\
\text { roughening. }\end{array}$ & & \\
\hline $3 \mathrm{C}$ & C-Mo & $S, R, D$ & & & \\
\hline $4 \mathrm{C}$ & $C-B e O$ & $\mathrm{R}, \mathrm{D}$ & No reaction & 0.044 & \\
\hline $5 \mathrm{C}$ & C-Re & S & $\begin{array}{l}\text { Re badly cracked, but there } \\
\text { was no evidence of reaction. }\end{array}$ & 0.380 & \\
\hline $6 \mathrm{C}$ & C- (Mo-50Re) & S,D & & & \\
\hline 7C & $C-(P t-R h-W)$ & $S, R, D$ & Reaction to depth of $\sim 1 \mathrm{mil}$ & 0.056 & \\
\hline Mo-3 & $\mathrm{Mo}-\mathrm{ZrO}_{2}$ & $C, F, N R$ & & & \\
\hline W-3 & $\mathrm{W}-\mathrm{ZrO}_{2}$ & $C, F, N R$ & & & \\
\hline $\mathrm{Ta}-3$ & $\mathrm{Ta}-\mathrm{ZrO}_{2}$ & $c, s$ & & & \\
\hline Mo-6 & $\mathrm{Mo}-\mathrm{HfO}_{2}$ & $C, F, S R$ & & & \\
\hline W-6 & $\mathrm{W}-\mathrm{HfO}_{2}$ & $C, N R$ & & & \\
\hline $\mathrm{Ta}-6$ & $\mathrm{Ta}-\mathrm{HfO}_{2}$ & $C, S R$ & & & \\
\hline Mo-9 & $\mathrm{Mo}-\mathrm{BeO}$ & NR & No reaction & & \\
\hline Mo-12 & Mo-BeO & NR & & & \\
\hline W-9 & $\mathrm{W}-\mathrm{BeO}$ & NR & & & \\
\hline$W-12$ & W-BeO & $\begin{array}{l}\text { W has etched } \\
\text { appearance }\end{array}$ & No reaction & & \\
\hline $\operatorname{Re}-2$ & $\mathrm{Re}-\mathrm{BeO}$ & NR & $\begin{array}{l}\text { Slight surface roughening. High } \\
\text { degree of twinning or deformation } \\
\text { lines in microstructure }\end{array}$ & & \\
\hline$\left(\begin{array}{ll}\text { Mo-50 } & \mathrm{Re}\end{array}\right)-2$ & $(\mathrm{Mo}-50 \mathrm{Re})-\mathrm{BeO}$ & NR & Slight surface roughening. & & \\
\hline Mo-15 & Mo-Re & $\mathbf{S}$ & & & \\
\hline W-15 & W-Re & s & & & \\
\hline$($ Mo-50 $R e)-4$ & $($ Mo-50 Re $)-I r$ & $\mathbf{R}$ & & & \\
\hline
\end{tabular}


Table 10. Summary of Weight Change Data on Compatibility Couples

\begin{tabular}{|c|c|c|c|c|c|c|}
\hline \multirow{3}{*}{ Couple } & \multicolumn{6}{|c|}{ Weight Change (mg) } \\
\hline & \multicolumn{2}{|c|}{$1300^{\circ} \mathrm{C}$} & \multicolumn{2}{|c|}{$1400^{\circ} \mathrm{C}$} & \multicolumn{2}{|c|}{$1500^{\circ} \mathrm{C}$} \\
\hline & C & Metal & $\mathrm{C}$ & Metal & C & Metal \\
\hline $\mathrm{C}-\mathrm{Ta}$ & a & $\mathbf{a}$ & $\mathbf{a}$ & a & -4.1 & +15.4 \\
\hline $\mathrm{C}-\mathrm{W}$ & -0.7 & 0 & -0.7 & 0 & -2.2 & +9.4 \\
\hline C-Mo & -7.7 & +13.5 & a & a & -1.2 & -58.6 \\
\hline $\mathrm{C}-\mathrm{BeO}$ & +0.6 & -2.3 & - & -3.6 & -5.6 & -75.7 \\
\hline$C-R e$ & $\mathbf{a}$ & $\mathbf{a}$ & $\mathbf{a}$ & $\mathbf{a}$ & $\mathbf{a}$ & $\mathbf{a}$ \\
\hline$C($ Mo-50Re) & $\mathbf{a}$ & a & -19 & +38.7 & $\mathbf{a}$ & $\mathbf{a}$ \\
\hline \multirow[t]{2}{*}{$C(P t-R h-W)$} & -1.2 & +2.0 & a & $\mathbf{a}$ & a & $\mathbf{a}$ \\
\hline & Oxide & Metal & Oxide & Metal & Oxide & Meta1 \\
\hline $\mathrm{Mo}-\mathrm{ZrO}_{2}$ & b & b & -10.6 & 0 & $\mathbf{b}$ & b \\
\hline $\mathrm{W}-\mathrm{ZrO}_{2}^{2}$ & b & b & -70.5 & +3.0 & b & b \\
\hline $\mathrm{Ta}-\mathrm{ZrO}_{2}$ & b & b & -41.8 & +1.4 & b & b \\
\hline $\mathrm{Mo}-\mathrm{HfO}_{2}$ & b & b & -116 & +8.3 & b & b \\
\hline $\mathrm{W}-\mathrm{HfO}_{2}^{2}$ & $b$ & b & -11.9 & +5.0 & b & b \\
\hline $\mathrm{Ta}-\mathrm{HfO}_{2}$ & b & b & -60.0 & +2.5 & b & b \\
\hline $\mathrm{Mo}-\mathrm{BeO}_{\mathrm{C}}$ & b & b & -5.5 & 0 & -6.0 & -0.2 \\
\hline $\mathrm{Mo}-\mathrm{BeO}^{\mathrm{C}}$ & b & b & -2.6 & 0 & $\mathrm{~b}$ & $\mathrm{~b}$ \\
\hline W-BeO & b & $\mathbf{b}$ & -4.6 & +7.0 & $\mathrm{~b}$ & $\mathbf{b}$ \\
\hline $\mathrm{W}-\mathrm{BeO}^{\mathrm{C}}$ & $\mathrm{b}$ & b & 0 & -2.5 & -1.9 & -610 \\
\hline $\mathrm{Re}-\mathrm{BeO}$ & $\mathrm{b}$ & b & -4.1 & +1.5 & -4.0 & 0 \\
\hline \multirow{2}{*}{$(\mathrm{Mo}-50 \mathrm{Re})-\mathrm{BeO}$} & $b$ & $\mathbf{b}$ & -4.1 & +1.0 & -5.7 & +4.2 \\
\hline & Metal 1 & Metal 2 & Metal 1 & Metal 2 & Metal 1 & Metal 2 \\
\hline$M o^{1}-R^{2}$ & $\mathrm{~b}$ & b & 0 & d & b & b \\
\hline$W^{1}-R^{2}$ & $\mathrm{~b}$ & $\mathrm{~b}$ & -1.5 & $\mathrm{~d}$ & $\mathrm{~b}$ & $\mathrm{~b}$ \\
\hline $\mathrm{W}^{1}-(\mathrm{Mo}-50 \mathrm{Re})^{2}$ & $\mathrm{~b}$ & b & 0 & +1.2 & $\mathrm{~b}$ & $\mathrm{~b}$ \\
\hline$(\text { Mo-50Re })^{1}-\mathrm{Ir}^{2}$ & b & b & +4.8 & -6.8 & +3.4 & -5.1 \\
\hline
\end{tabular}




\section{INTERNAL}

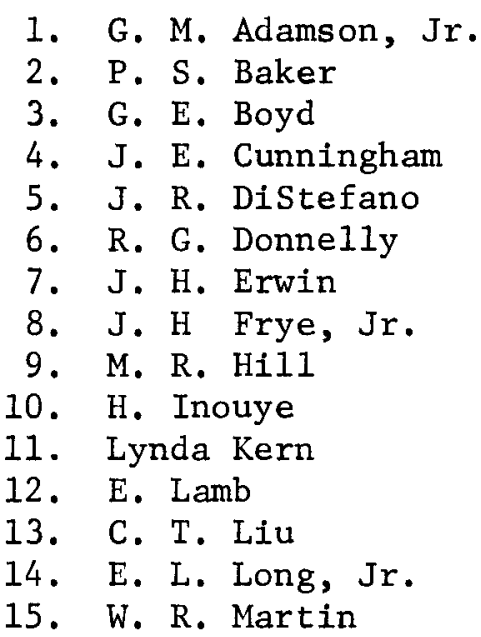

16. H. C. McCurdy

17. R. E. McDonald

18. R. E. McHenry

19. P. Patriarca

20. R. A. Robinson

21. A. F. Rupp

22. A. C. Schaffhauser

23. D. B. Trauger

24. J. R. Weir

25-26. Central Research Library

27. Document Reference Section

28-29. Laboratory Records

30. Laboratory Records, ORNL-RC

31. ORNL Patent Office

\section{EXTERNAL}

32. R. Andelin, Donald W. Douglas Laboratories

33-34. R. D. Baker, Los Alamos Scientific Laboratory

35. V. Berniklau, Albuquerque Area Office, AEC

36. W. Brooksbank, G. C. Marshall Space Flight Center, NASA

37. R. Brouns, Langley Research Center, NASA

38. R. T. Carpenter, Division of Space Nuclear Systems, AEC

39. W. T. Cave, Monsanto Research Corporation

40. G. R. Crane, Andrews AFB

41. D. D. Davis, Dayton Area Office, AEC

42. G. Deutsch, NASA Headquarters

43. G. P. Dix, Division of Space Nuclear Systems, AEC

44. J. Epstein, Goddard Space Flight Center, NASA

45. R. Fische11, Johns Hopkins University

46. N. Goldenberg, Division of Space Nuclear Systems, AEC

47. R. J. Hart, AEC-ORO

48. A. Hoffman, TRW Systems

49. W. S. Hollman, Division of Applied Technology, AEC

50. R. G. Ivanoff, Jet Propulsion Laboratory

51. H. Jaffe, Division of Space Nuclear Systems, AEC

52. T. B. Kerr, NASA Headquarters

53. M. Klein, Division of Space Nuclear Systems, AEC

54. G. Linkous, Isotopes, Inc.

55. J. J. Lombardo, Lewis Research Center, NASA

56. M. MacWilliams, Kirtland AFB

57. J. McDonald, Sandia Laboratories

58. H. Nelson, Ames Research Center, NASA

59. G. A. Newby, Division of Space Nuclear Systems, AEC

60. A. Noonan, Kirtland AFB

61. W. Pardue, Battelle Memorial Institute

62. A. A. Pitrolo, General Electric Company

63. T. W. Redding, Manned Spacecraft Center

64. F. Schulman, AEC Headquarters 
65. M. Shaw, Division of Reactor Development and Technology, AEC

66. R. W. Shivers, Division of Applied Technology, AEC

67. J. M. Simmons, Division of Reactor Development and Technology, AEC

68. H. C. Slone, Lewis Research Center

69. M. D. Starr, Naval Facilities Engineering Command

70. R. Valle, Monsanto Research Corporation

71. E. J. Wahlquist, Division of Space Nuclear Systems, AEC

72. A. Wilbur, Ames Research Center, NASA

73. Research and Technical Support Div., ORO

74-75. Technical Information Center, OR 